158

Received: May 10, 2012

Accepted: December 10, 2012
Macedonian Journal of Animal Science, Vol. 3, No. 1, pp. 115-120 (2013)

In print ISSN $1857-6907$

On line ISSN $1857-7709$

UDC:334.722.012.641.65:316.334.55(497.7)

Original scientific paper

\title{
IMPACT OF THE SIZE OF ENTERPRISES IN RURAL AREAS OF THE REPUBLIC OF MACEDONIA ON ATTITUDES TOWARDS ENTREPRENEURSHIP
}

\author{
Tošo Kostadinov \\ "Ss. Cyril and Methodiys" University in Skopje, Institute of Animal Science, \\ Bul. Ilinden 92-a, Skopje, Republic of Macedonia \\ tosokostadinov@gmail.com
}

\begin{abstract}
The aim of this paper is to investigate how the size of enterprises affects attitudes towards entrepreneurship. For this purpose a survey on 101 respondents from rural areas in the Republic of Macedonia, of which $20.8 \%$ were owners of small enterprises and $75.8 \%$ of micro enterprises, was conducted. Five sets of statements that are important for comparison of the attitudes towards entrepreneurship among small and micro enterprises were offered. $4 \%$ of the respondents were owners of medium-sized enterprises, which due to the low percentage of participation in the survey were excluded from analysis. The responses are valued at a five-degree scale from 1 - irrelevant to 5 - priority. The results of this research indicate that the size of enterprises in rural areas positively affect attitudes towards entrepreneurship. Generally speaking, respondents from small businesses in rural areas have more positive attitudes towards entrepreneurship, than those in micro enterprises.
\end{abstract}

Key words: entrepreneurship; enterprise; micro enterprise; small enterprise; attitudes towards entrepreneurship

\section{ВЛИЈАНИЕТО НА ОДНОСОТ СПРЕМА ПРЕТПРИЕМНИШТВОТО ВРЗ ГОЛЕМИНАТА НА ПРЕТПРИЈАТИЈАТА ВО РУРАЛНИТЕ ПОДРАЧЈА НА РЕПУБЛИКА МАКЕДОНИЈА}

Целта на овој труд е да се истражи како големината на претпријатијата влијае врз ставовите спрема претприемништвото. За таа цел е спроведено анкетно истражување на 101 испитаник од руралните подрачја, од кои $20,8 \%$ се сопственици на мали претпријатија, а $75,8 \%$ на микропретпријатија, на кои им се понудени пет сета искази кои се од значење за споредба на ставовите спрема претприемништвото помеѓу малите и микропретпријатија. 4\% од испитаниците се сопственици на средни претпријатија, кои поради нискиот процент на застапеност во анкетното истражување се исклучени од анализата. Одговорите се вреднувани по петостепена скала од 1 - неважно до 5 - приоритет. Истражувањето укажа дека големината на претпријатијата во руралните подрачја позитивно влијае врз ставовите спрема претприемништвото. Малите претпријатија од руралните подрачја, генерално земено, имаат попозитивни ставови спрема претприемништвото споредено со микропретпријатијата.

Клучни зборови: претприемништво; претпријатие; микропретпријатие; мало претпријатие; ставови спрема претприемништво

\section{INTRODUCTION}

The basic problem with the division of enterprises according to their size is the choice of indicators of size. Usually, the size of enterprises is expressed by the number of employees, amount of capital that a company owns, the amount of total income of the company, the amount of profits and the like.

In the Republic of Macedonia, according to size, enterprises are classified as micro, small, medium and large.

The classification of enterprises by the Law on trade companies was prepared in accordance 
with the definition used in the EU. However, some small adjustments in the values of the EU defini- tions were made in order to accept the definition of EU as national.

Table 1

Division criteria of enterprises

\begin{tabular}{|c|c|c|}
\hline \multicolumn{2}{|c|}{ Law on trade companies $(2004)$} & Law on accounting (1993), amended in 2002 \\
\hline \multicolumn{3}{|c|}{ Two of the following criteria have to be met during the first year of work } \\
\hline \multirow[t]{3}{*}{ Micro } & Up to 10 employees & \\
\hline & Annual income $<50.000 €$ & \\
\hline & At most $80 \%$ of gross income derives from one customer & \\
\hline \multirow[t]{3}{*}{ Small } & up to 50 employees & Up to 50 employees \\
\hline & The total income / turnover is $<2.000 .000 €$ & Annual income $<8.000$ average monthly wages per employee \\
\hline & The value of assets $<2.000 .000 €$ & $\begin{array}{l}\text { The Value of assets is }<6.000 \text { average monthly wages per } \\
\text { employee }\end{array}$ \\
\hline \multirow[t]{3}{*}{ Medium } & up to 250 employees & Up to 250 employees \\
\hline & Annual income $<10.000 .000 €$ & $\begin{array}{l}\text { Annual income }<40.000 \text { Average monthly wages per } \\
\text { employee }\end{array}$ \\
\hline & The value of assets $<11.000 .000 €$ & $\begin{array}{l}\text { The value of assets is }<30.000 \text { Average monthly wages per } \\
\text { employee }\end{array}$ \\
\hline Large & All that do not belong to the above stated classifications & \\
\hline
\end{tabular}

Source: Ministry of Economy, European Charter for Small Enterprises, National Report 2005

\section{MATERIAL AND METHODS}

The aim of this research is based on literature, documents, and particularly based on the analysis of interviewed representative sample of entrepreneurs (101 SMEs), of which $75.2 \%$ were micro enterprises, $20.8 \%$ small enterprises and $4 \%$ medium enterprises in order to gain some knowledge about the similarities and differences in their attitudes towards entrepreneurship between micro and small enterprises in the rural areas in Macedonia. Medium-sized enterprises are excluded from this analysis because of their low percentage of participation in the survey. During the preparation of this work more commonly applied methods in the economic analysis were applied, especially the comparative method, the method of generalization and specialization, the method of induction and deduction and the statistical method.

\section{RESULTS AND DISCUSSION}

The survey respondents were presented five sets of statement that are of importance for comparison of the participants' attitudes towards entre- preneurship between micro and small enterprises in rural areas of the Republic of Macedonia, valued at a five-degree scale from 1 - unimportant to 5 - priority (Table 2, Table 3 , Table 4 , and Table 5 and Table 6).

In the set of questions related to the promotion of the enterprise in order to be more competitive, compared by the size of enterprises, respondents from small businesses generally demonstrate higher levels of agreement than those from micro enterprises. In contrast to respondents from micro companies employees from small companies gave higher assessments to the following claims such as improving the quality of products/services, enhancement of the promotion of products, obtaining of quality certificates, expert technical assistance, training and education in the field of entrepreneurship, development and education in science, training and education in management, training and education in the field of marketing, bringing together companies from their sector for joint market appearance, aid by development assistance programs through grants, development assistance programs through favorable loans and development assistance programs through guarantee funds. Re- 
spondents from micro enterprises feel a greater need for training and education in finance and marketing.

In the set of questions concerning plans for the businesses in future, compared by the size of the enterprises, respondents from small firms gave higher ratings compared to those from micro companies to all offered statements such as adding new products or services, sale on new markets, research of new markets, search for new distribution channels, expanding advertising and promotion, investment in new equipment and machinery, replacement of current devices and machines, expanding of current facilities/plants, redesign/new arrangement of current facilities, search for additional financial capital, computerization of current operations, upgrade of computer systems, redesign of work activities, expanding the scope of working activities, search for professional or technical ad- vice, additional engagement of staff specialists and investing in staff training (elsewhere/not in the company).

In the set of questions related to allegations concerning entrepreneurship, compared by the size of business, respondents from small companies have more positive attitudes than those in micro enterprises. Most positively rated attitude in this set of issues regarding attitudes toward entrepreneurship, is the attitude "I would rather have my own business than to earn higher wages working for someone else", especially by respondents from small enterprises.

The group of questions about the attitudes in the community towards entrepreneurs, compared by the size of the company are lowly rated. All answers that came from small companies are more positive than those from micro enterprises.

Table 2

Agreement with the statements in terms of improving the work for more competitive market position compared by the number of employees

\begin{tabular}{llll}
\hline \hline & & Mean value \\
& Up to 9 & 10 to 50 & Total \\
\hline Improving the quality of products and services & 4.13 & 4.29 & 4.17 \\
Improving the promotion of products & 4.14 & 4.38 & 4.20 \\
Obtaining certifications for quality & 3.92 & 4.38 & 4.03 \\
Professional consulting assistance & 3.28 & 4.04 & 3.46 \\
Improvement and education in the field of entrepreneurship & 3.72 & 4.17 & 3.83 \\
Improvement and education in the field of IT & 3.79 & 4.17 & 3.88 \\
Improvement and education in the field of management & 3.75 & 4.08 & 3.83 \\
Improvement and education in finance & 3.69 & 3.54 & 3.66 \\
Improvement and education in the field of sales & 3.91 & 3.83 & 3.89 \\
Improvement and education in marketing & 3.88 & 4.00 & 3.91 \\
Improvement and education in foreign languages & 3.38 & 3.38 & 3.38 \\
Association with companies in the sector to appear jointly on the market & 3.11 & 4.21 & 3.37 \\
Assistance from development programs through grants & 4.24 & 4.52 & 4.31 \\
Assistance from development programs through favorable loans & 4.20 & 4.60 & 4.30 \\
Assistance from development programs through guarantee funds & 3.61 & 4.40 & 3.80 \\
\hline \hline
\end{tabular}

Source: Own calculations 
Table 3

Agreement with the statements in terms of business plans for the future compared by the number of employees

\begin{tabular}{|c|c|c|c|}
\hline & \multicolumn{3}{|c|}{ Mean value } \\
\hline & Up to 9 & 10 to 50 & Total \\
\hline Introducing new products or services & 3.97 & 4.40 & 4.08 \\
\hline Sales on a new market & 3.08 & 4.24 & 3.37 \\
\hline Exploring new markets & 3.01 & 4.24 & 3.32 \\
\hline Search for new distribution channels & 3.42 & 4.21 & 3.61 \\
\hline Expanding advertising and promotion & 3.75 & 4.24 & 3.87 \\
\hline Investing in new equipment and machinery & 3.51 & 4.24 & 3.69 \\
\hline Replacement of current equipment and machinery & 3.49 & 4.48 & 3.73 \\
\hline Expansion of current facilities & 3.42 & 4.48 & 3.68 \\
\hline Redesign/new arrangement of the current facilities & 3.16 & 4.20 & 3.42 \\
\hline Search for additional financial capital & 3.76 & 4.40 & 3.92 \\
\hline Computerization of current operations & 3.11 & 3.84 & 3.29 \\
\hline Upgrading of computer systems & 3.26 & 3.72 & 3.38 \\
\hline Redesign of work activities & 3.12 & 3.80 & 3.29 \\
\hline Expanding the scope of work activities & 3.59 & 4.32 & 3.77 \\
\hline Search for professional or technical advice & 3.33 & 3.84 & 3.46 \\
\hline Additional engagement of staff specialists & 3.14 & 4.08 & 3.38 \\
\hline Investing in staff training (elsewhere / not in the company) & 2.41 & 3.32 & 2.63 \\
\hline
\end{tabular}

Source: Own calculations

Table 4

Agreement with the statements about entrepreneurship, compared by the number of employees

\begin{tabular}{|c|c|c|c|}
\hline & \multicolumn{3}{|c|}{ Mean value } \\
\hline & Up to 9 & 10 to 50 & Total \\
\hline My business is the most important activity in my life & 4.01 & 4.48 & 4.13 \\
\hline I would do everything that is needed for my business to succeed & 4.07 & 4.52 & 4.18 \\
\hline I plan to sell my business at the end & 2.25 & 1.84 & 2.15 \\
\hline I would like to contribute significantly to the community by developing a successful business & 4.18 & 4.60 & 4.29 \\
\hline I would prefer to have my own business than to earn higher wages working for someone else & 4.21 & 4.48 & 4.33 \\
\hline To run your own business is more important than have more time for the family & 3.80 & 3.80 & 3.80 \\
\hline I would prefer to have my own business than to have another promising career & 4.01 & 4.28 & 4.08 \\
\hline $\begin{array}{l}\text { For the entrepreneur it is important to understand and accept the risk in order to start and run a } \\
\text { successful business }\end{array}$ & 4.14 & 4.60 & 4.26 \\
\hline I am ready to get into conflict with my family for the sake of running my business & 3.70 & 3.72 & 3.70 \\
\hline I would put my house mortgaged to acquire capital for my business & 3.25 & 4.36 & 3.52 \\
\hline I would be ready to have less security for my family in order to run my business & 3.58 & 3.96 & 3.67 \\
\hline I run my business to continue the family tradition & 3.16 & 3.88 & 3.34 \\
\hline I run my business to contribute to the welfare of my relatives & 3.45 & 3.76 & 3.52 \\
\hline I run my business to live in a place that my family likes & 3.41 & 3.64 & 3.47 \\
\hline I run my business to improve the status and prestige of my family & 3.96 & 4.20 & 4.02 \\
\hline I run my business to have more flexibility in my personal and family life & 4.12 & 3.96 & 4.08 \\
\hline
\end{tabular}

Source: Own calculations 
Table 5

Agreement with the statements in the community compared by the number of employees

\begin{tabular}{lccc}
\hline \hline & \multicolumn{3}{c}{ Mean value } \\
\cline { 2 - 4 } & Up to 9 & 10 to 50 & Total \\
\hline Many people in my community would like to create and grow a business & 2.72 & 2.84 & 2.75 \\
$\begin{array}{l}\text { Many people in my community really support entrepreneurs when they fail and make attempts } \\
\text { again with a new business }\end{array}$ & 2.63 & 2.80 & 2.67 \\
$\begin{array}{l}\text { Many people in my community support someone who creates a new or expands an existing } \\
\text { business }\end{array}$ & 2.59 & 2.76 & 2.63 \\
$\begin{array}{l}\text { Many people in my community would encourage a young person to engage with career } \\
\text { establishment and growth of a business }\end{array}$ & & & \\
Many people in my community would like to create and grow a business & 2.97 & 3.12 & 3.01 \\
\hline \hline
\end{tabular}

Source: Own calculations

Table 6

Agreement with the statements in terms of support for the entrepreneurship compared by the number of employees

\begin{tabular}{|c|c|c|c|}
\hline & \multicolumn{3}{|c|}{ Mean value } \\
\hline & Up to 9 & 10 to 50 & Total \\
\hline My community respects and celebrates people who create and grow local businesses & 2.87 & 2.68 & 2.82 \\
\hline $\begin{array}{l}\text { My community has developed programs to encourage and support entrepreneurs who work on } \\
\text { development and growth }\end{array}$ & 2.72 & 2.36 & 2.63 \\
\hline In my community programs for micro-loans are being considered & 2.70 & 2.48 & 2.64 \\
\hline My community offers training for business and entrepreneurship & 3.14 & 2.48 & 2.98 \\
\hline $\begin{array}{l}\text { My community creates conditions for networking and monitoring of the opportunities for entrepreneurs } \\
\text { and people from the local business }\end{array}$ & 2.68 & 2.20 & 2.56 \\
\hline My community needs venture capital and / or angel investors & 3.38 & 3.64 & 3.45 \\
\hline
\end{tabular}

Source: Own calculations

In the group of statements related to the support of entrepreneurship, compared by the size of the company - except the attitude about the need for venture capital and/or angel investors in their community - the assessments obtained by respondents from small enterprises are lower than those of micro enterprises. These attitudes are relatively lowly assessed.

\section{CONCLUSION}

The results of this research indicate that the size of enterprises in rural areas positively affects attitudes towards entrepreneurship. Respondents from small businesses in rural areas generally have more positive attitudes towards entrepreneurship, compared to those in micro enterprises.

Stimulating the growth of micro enterprises and their conversion to small businesses by the state and local government and establishment of small enterprises will have positive impacts upon the entrepreneurship and economic vitality of rural areas in Macedonia.

\section{REFERENCES}

[1] Coase R. (1953): The Nature of the Firm, Economica, New Series, Vol. IV. Препечатено во: Stigler, G., Boulding, $\mathrm{K}$ - American Economic Association Readings in Price Theory, Homewood, III, Richard D. Irwin. 
[2] Daft R. L. (1998): Essentials of Organizational Theory and Design, South-Western College Publishing.

[3] Koontz H., Fulmer R. (1990): Ključni faktori poduzetništva (Business), NSRO Oslobodjenje, Sarajevo.

[4] Mansfield E. (1975): Microeconomic: Theory and Applications, W.W. Norton, New York,
[5] Министерство за економија на РМ: Евройска йовелба за

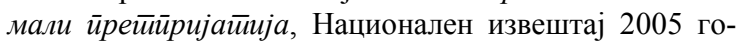
дина (2005).

[6] Paunović B. (2008): Ekonomika preduzeća: preduzeće, okruženje i ulaganja, CID, Beograd.

[7] Peters, H. (1998): Entrepreneurship, Irwin.. 